\title{
Systematic status of Systomus rubrotinctus Jerdon (Teleostei: Cyprinidae) with notes on the Puntius arulius group of fishes
}

\author{
J.D. Marcus Knight ${ }^{1}$, K. Rema Devi $^{2}$ \& Vidyadhar Atkore ${ }^{3}$ \\ ${ }^{1}$ Flat 'L', Sri Balaji Apartments, $7^{\text {th }}$ Main Road, Dhandeeswaram, Velachery, Chennai, Tamil Nadu 600042, India \\ ${ }^{2}$ Zoological Survey of India, Southern Regional Centre, 100, Santhome High Road, Chennai, Tamil Nadu 600028 \\ ${ }^{3}$ ATREE, Royal Enclave, Sriramapura, Jakkur Post, Bengaluru, Karnataka 560064, India \\ Email: ${ }^{1}$ jdmarcusknight@yahoo.co.in, ${ }^{2}$ remadevi_zsi@yahoo.com (corresponding author), ${ }^{3}$ vidyadhar.atkore@gmail.com
}

Date of publication (online): 26 April 2011 Date of publication (print): 26 April 2011 ISSN $0974-7907$ (online) | 0974-7893 (print)

Editor: Anonymity requested

Manuscript details:

Ms \# 02684

Received 27 January 2011

Final received 11 April 2011

Finally accepted 13 April 2011

Citation: Knight, J.D.M., K.R. Devi \& V. Atkore (2011) Systematic status of Systomus rubrotinctus Jerdon (Teleostei: Cyprinidae) with notes on the Puntius arulius group of fishes. Joumal of Threatened Taxa 3(4): 1686-1693.

Copyright: ( ) J.D. Marcus Knight, K. Rema Devi \& VidyadharAtkore 2011. Creative Commons Attribution 3.0 Unported License. JoTT allows unrestricted use of this article in any medium for non-profit purposes, reproduction and distribution by providing adequate credit to the authors and the source of publication.

Author Details: J.D. MARCUS KNIGHT is a naturalist based in Chennai. Amongst others, his interest is in exploring the freshwater habitats and is currently studying the Puntius filamentosus group of fishes. K. REMA DEVI is a senior scientist in the Southern Regional Centre of the Zoological Survey of India and an ichthyologist who has published over hundred papers including descriptions of several new species. VIDYADHAR ATKORE is a PhD student at ATREE working on conservation biology of native freshwater fishes in the Western Ghats, India. His interest lies in the community ecology of fishes and river restoration.

Author Contributions: JDMK recognized the validity of $P$. rubrotinctus and initiated the study. He speculated natural hybridization and all putative hybrids were collected by him. All the photographs used in the paper were provided by him. KRD carried out the morphometric study to distinguish P. rubrotinctus as a valid species. She provided help in writing the paper VA also provided comparative material and helped in the morphometric study.

Acknowledgements: We wish to thank the Director Zoological Survey of India, Kolkata for the facilities provided and Rohan Pethiyagoda for his help in designating the Neotype. We also wish to thank Andrew Rao, Ashwin Rai, Rahul Kumar, Balal Vijayakrishnan, Beta Mahatvaraj, Madhusoodhanan, Prasoon Nair, Shankar Balasubramanian and Sadashiv Nayak for helping us obtain comparative material of the Puntius filamentosus group of fishes from various drainages and sharing their unpublished field notes.

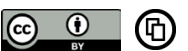

OPEN ACCESS | FREE DOWNLOAD
Abstract: Systomus rubrotinctus Jerdon has long been considered a synonym of Puntius arulius. Examination of ' $P$. arulius' collected from various parts of the Western Ghats revealed the presence of two distinct species: and the fish considered by Day as ' $P$. arulius' from Wayanad is in fact $P$. rubrotinctus. Based on the colour pattern, morphometrics and meristics, $P$. rubrotinctus is retrieved from the synonymy of $P$. arulius and redescribed. Puntius rubrotinctus can be distinguished from $P$. arulius by the unique colour pattern consisting of three well-defined black blotches on the body, two scales high and three scales wide, as distinct from the diffused blotches in $P$. arulius. It further differs from $P$. arulius in having a shorter dorsal-to-hypural distance $(49.8-54.6 \% \mathrm{SL}$, vs. $57.3-57.6 \% \mathrm{SL})$, a smaller interorbital width $(28.4-35.6 \% \mathrm{HL}$, vs. $39.1-39.7 \% \mathrm{HL})$ and a higher number of gill rakers (10-11 in the first gill arch, vs. 8). Puntius rubrotinctus is wide distributed in the Cauvery River and its tributaries in the Western Ghats region across the states of Kerala, Karnataka and Tamil Nadu. The results revalidate the identity of the 'Puntius filamentosus group' of previous authors drawing attention to the presence of intermediate forms among this group, in which natural hybrids appear to occur, of which $P$. exclamatio may be one.

Keywords: Cyprinids, natural hybridization, Puntius exclamatio, $P$. filamentosus, $P$. tambraparniei, revalidation.

\section{INTRODUCTION}

Jerdon(1849) described two barbs, Systomus arulius and S. rubrotinctus, now be referred to Puntius. These fishes possess three black blotches on the body, the former with large diffused blotches, and the latter with smaller blotches. Jerdon described $P$. arulius as having "a large diffused black spot on side beneath the commencement of the dorsal fin, another over the anal, and another at base of caudal" and in the same work he described $P$. rubrotinctus a species with " 3 small black spots on sides, one under dorsal, the $2^{\text {nd }}$ over the anal and the $3^{\text {rd }}$ near base of caudal". Though Jerdon (1849) does not give the exact type locality of $P$. arulius and $P$. rubritinctus, he mentions that $P$. arulius is called 'aruli' at Seringapatam [=Shrirangapattana] in Karnataka and that he procured P. rubrotinctus from the Manantoddy River (= Mananthavadi River) in Kerala. Subsequently, Day (1878) placed $P$. rubrotinctus in the synonymy of P. arulius. During an examination of the specimens deposited in the Southern Regional Centre, Zoological Survey of India and recent collections from the Western Ghats, the presence of two distinct species fitting the description of $P$. arulius and P. rubrotinctus given by Jerdon (1849) were observed. In this paper we retrieve $P$. rubrotinctus from its synonymy with $P$. arulius and distinguish it from its closely related congeners $P$. arulius, $P$. tambraparniei and $P$. 
srilankensis, which we here refer to as the $P$. arulius group of fishes owing to their shared gross adult colour pattern.

\section{MATERIALS AND METHODS}

The material for the present study is based mostly on the specimens from earlier surveys in the collections of the Southern Regional Centre of the Zoological Survey of India and recent collections from Bhadra River, Karnataka and Tambraparni River, Tamil Nadu (Fig. 1). The other specimens used in this study are registered in the Reserve Collections of the Zoological Survey of India, Southern Regional Centre, Chennai (ZSI/SRS) and Zoological Survey of India, Western Ghats Regional Centre, Kozhikode (ZSI/WGRC). Measurements were taken using a dial caliper to the nearest $0.1 \mathrm{~mm}$. Quantification of characters follows Devi et al. (2010). Subunits of the head are expressed in proportions of head length (HL). Numbers in parenthesis after a count denote the frequency of that

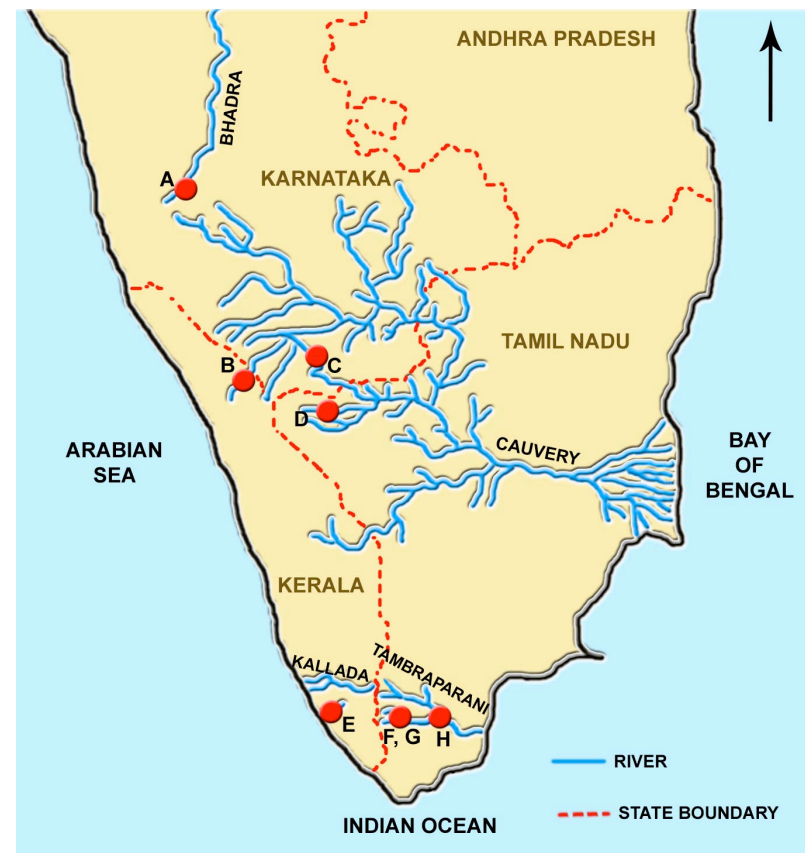

Figure 1. Descriptive map of southern peninsular India, showing the various locations from which $P$. arulius group of fishes were examined in this present study: A - KIOCL plant, Bhadra River; B - Khabini river; C - Bhavali River; D - Mavanahalla, Moyar River; E - Varkhala, Kallada River; F - Kodaimel Azhakian Anicut, Tambraparani River; G Cheremadevi, Tambraparani River; H - Tirunelveli Town, Tambraparani River. (Map not to scale) count. Specimens of $P$. srilankensis were not examined and the data in Pethiyagoda \& Kottelat (2005) was used for comparison.

\section{Puntius rubrotinctus (Jerdon, 1849)}

(Images 1, 2A; Table 1.)

Puntius arulius Day, 1878: p 575, Plate CXLII, fig. 5.

Material examined: Putative topotypes - 2 ex., 71.8-86.2 mm SL, Kabini River, (date: unknown), ZSI/SRS F.8373, coll. R.S. Lal Mohan. The smaller specimen $71.8 \mathrm{~mm}$ SL is designated as the neotype.

Others: 6 ex., $65.0-80.0 \mathrm{~mm}$ SL, Mavanahalla, Moyar River drainage ( $\left.11^{0} 31^{\prime} \mathrm{N} \& 76^{\circ} 42^{\prime} \mathrm{E}\right)$, Nilgiris District, Tamil Nadu, ZSI/WGRC F.5077, coll. K.N. Nair; 07.xii.1985, 4 ex., 62.7-74.0 mm SL, Bhavali River drainage ( $\left.11^{0} 55^{\prime} \mathrm{N} \& 76^{\circ} 45^{\prime} \mathrm{E}\right)$, Coorg District, Karnataka, ZSI/WGRC F.3954, coll. K.N. Nair.

\section{Designation of Neotype}

As a thorough search of Jerdon's collections maintained in the Senckenberg Natural History Museum, Frankfurt and British Museum of Natural History, London revealed no specimen of Puntius rubrotinctus (R. Pethiyagoda, pers. comm.), a neotype is designated to stabilize the identity of Puntius rubrotinctus to differentiate it from $P$. arulius. As the type locality of $S$. rubrotinctus is the Manantoddy River (= Mananthavadi River) which falls in the Kabini River drainage from where the putative topotypes (ZSI/SRS F.8373) were collected, we designate the more intact smaller topotype $(71.8 \mathrm{~mm}$ SL, ZSI/SRS F.8373) as neotype as it was collected as nearly as practicable from the original type locality. The presence of three small black blotches on sides, one under dorsal, the $2^{\text {nd }}$ over the anal and the $3^{\text {rd }}$ near base of caudal, consistent with the original description by Jerdon, clearly distinguishes it from $P$. arulius, which has three large diffused black blotches on the side (Jerdon 1849). The photograph (Image 1) and the morphometric data of the neotype is provided in Table 1. to ensure recognition of the specimen designated. The neotype belongs to the registered collections of the Southern Regional Centre, Zoological Survey of India which is a recognized scientific institution that maintains a research collection, with proper facilities for preserving name-bearing types, and makes them accessible for study. 


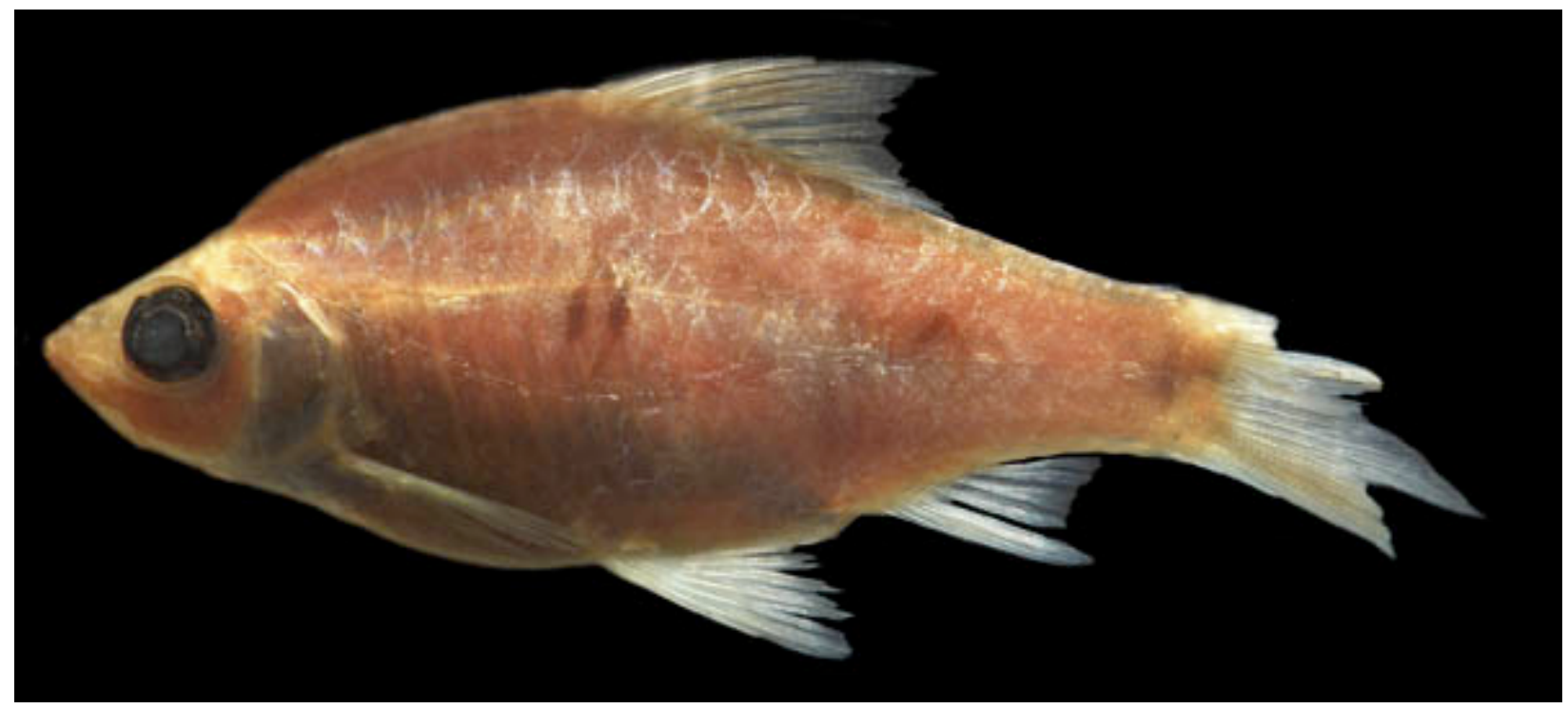

Image 1. Puntius rubrotinctus Neotype, $71.8 \mathrm{~mm}$ SL, ZSI/SRS F.8373

\section{Diagnosis}

Adult $P$. rubrotinctus can be distinguished from the other members of the $P$. arulius group of fishes by having a unique colour pattern of three well defined blotches two scale high and three scales wide restricted to the sides of the body when compared to the large diffused blotches in P. arulius (Image 2D), $P$. tambraparniei (Image 2E) and P. srilankensis. It further differs from $P$. arulius in having a shorter dorsal to hypural distance of $49.8-54.6 \%$ SL (vs.

Table 1. Morphometric data of P. rubrotinctus (ZSI/SRS F.8373; ZSI/WGRC F.5077 and F.3954), P. arulius (ATREE unregistered), P. tambraparniei (ZSI/SRS F.4452) and P. srilankensis (Pethiyagoda \& Kottelat 2005)

\begin{tabular}{|c|c|c|c|c|c|c|c|c|c|}
\hline \multirow[t]{2}{*}{ Characters } & \multicolumn{3}{|c|}{$P$. rubrotinctus $\mathrm{n}=12$} & \multicolumn{2}{|c|}{$P$. arulius $\mathrm{n}=3$} & \multicolumn{2}{|c|}{ P. tambraparniei $\mathrm{n}=10$} & \multicolumn{2}{|c|}{ P. srilankensis $\mathrm{n}=8$} \\
\hline & Range & Mean \pm SD & neotype & Range & Mean \pm SD & Range & Mean \pm SD & Range & Mean \pm SD \\
\hline Standard length [mm] & $62.7-86.2$ & & 71.8 & $69.5-79.8$ & & $40.3-53.2$ & & $64.3-77.8$ & \\
\hline \multicolumn{10}{|l|}{$\% \mathrm{SL}$} \\
\hline Head length & $28.3-32.8$ & $30.0 \pm 1.6$ & 29.1 & $26.4-28.0$ & $27.1 \pm 1.1$ & $24.6-30.0$ & $27.8 \pm 1.6$ & $24.8-26.7$ & $25.6 \pm 0.8$ \\
\hline Head depth & $19.0-23.2$ & $20.9 \pm 1.4$ & 21.8 & $22.0-22.5$ & $22.2 \pm 0.3$ & $18.3-21.6$ & $20.3 \pm 1.1$ & - & - \\
\hline Predorsal length & $49.2-55.3$ & $52.2 \pm 1.6$ & 53.6 & $51.8-52.3$ & $52.1 \pm 0.3$ & $49.5-56.4$ & $53.0 \pm 2.5$ & $49.5-52.6$ & $50.9 \pm 1.3$ \\
\hline Dorsal to hypural distance & $49.8-54.6$ & $52.5 \pm 1.6$ & 54.5 & $57.3-57.6$ & $57.5 \pm 0.2$ & $49.5-53.7$ & $51.5 \pm 1.2$ & $52.6-55.5$ & $54.5 \pm 0.9$ \\
\hline Maximum body depth & $34.9-41.8$ & $37.5 \pm 2.2$ & 41.8 & $37.0-38.1$ & $37.6 \pm 0.7$ & $32.6-39.0$ & $35.4 \pm 2.1$ & $28.0-31.9$ & $29.9 \pm 1.4$ \\
\hline Maximum body width & $12.2-17.9$ & $15.4 \pm 1.8$ & 17.9 & $15.9-19.1$ & $17.5 \pm 2.2$ & $13.3-16.8$ & $14.9 \pm 1.0$ & $16.2-19.3$ & $17.1 \pm 1.1$ \\
\hline Caudal peduncle length & $11.8-18.4$ & $16.3 \pm 1.9$ & 14.3 & $17.1-17.6$ & $17.3 \pm 0.3$ & $12.8-17.0$ & $15.5 \pm 1.3$ & $18.5-21.4$ & $19.7 \pm 0.9$ \\
\hline Caudal peduncle depth & $13.1-15.1$ & $14.1 \pm 0.6$ & 14.9 & $14.1-15.1$ & $14.6 \pm 0.7$ & $13.7-15.9$ & $14.6 \pm 0.5$ & $10.9-13.3$ & $12.5 \pm 0.8$ \\
\hline \multicolumn{10}{|l|}{$\% \mathrm{HL}$} \\
\hline Snout length & $25.2-30.6$ & $28.1 \pm 1.9$ & 25.8 & $25.5-29.0$ & $27.2 \pm 2.4$ & $25.8-29.1$ & $27.6 \pm 1.0$ & $25.9-34.2$ & $31.5 \pm 2.5$ \\
\hline Eye diameter & $29.3-35.8$ & $33.2 \pm 1.9$ & 34.4 & $33.4-34.2$ & $33.8 \pm 0.5$ & $35.0-41.7$ & $38.4 \pm 2.4$ & $25.5-30.4$ & $28.8 \pm 1.8$ \\
\hline Interorbital width & $28.4-35.6$ & $32.5 \pm 2.1$ & 34.4 & $39.1-39.7$ & $39.4 \pm 0.4$ & $28.3-35.8$ & $33.1 \pm 2.3$ & $37.8-42.5$ & $41.0 \pm 1.4$ \\
\hline Internarial width & $18.7-25.7$ & $22.1 \pm 2.2$ & 24.8 & $25.0-26.3$ & $25.6 \pm 0.9$ & $15.8-22.8$ & $18.9 \pm 2.0$ & $21.5-24.4$ & $23.2 \pm 1.1$ \\
\hline Length of maxilla & $26.5-32.3$ & $28.8 \pm 1.9$ & 28.7 & $28.1-29.8$ & $29.0 \pm 1.2$ & $19.0-21.6$ & $20.5 \pm 0.8$ & - & - \\
\hline Maxillary barbel length & $7.3-13.4$ & $10.6 \pm 2.1$ & 11.9 & $19.0-23.2$ & $21.1 \pm 2.9$ & $11.7-16.7$ & $14.1 \pm 1.5$ & $0.0-1.8$ & $1.1 \pm 0.7$ \\
\hline Postorbital head length & $38.7-47.5$ & $43.2 \pm 2.5$ & 43.5 & $47.7-52.7$ & $50.2 \pm 3.4$ & $34.1-47.2$ & $42.1 \pm 4.2$ & $39.5-45.4$ & $42.6 \pm 2.2$ \\
\hline
\end{tabular}




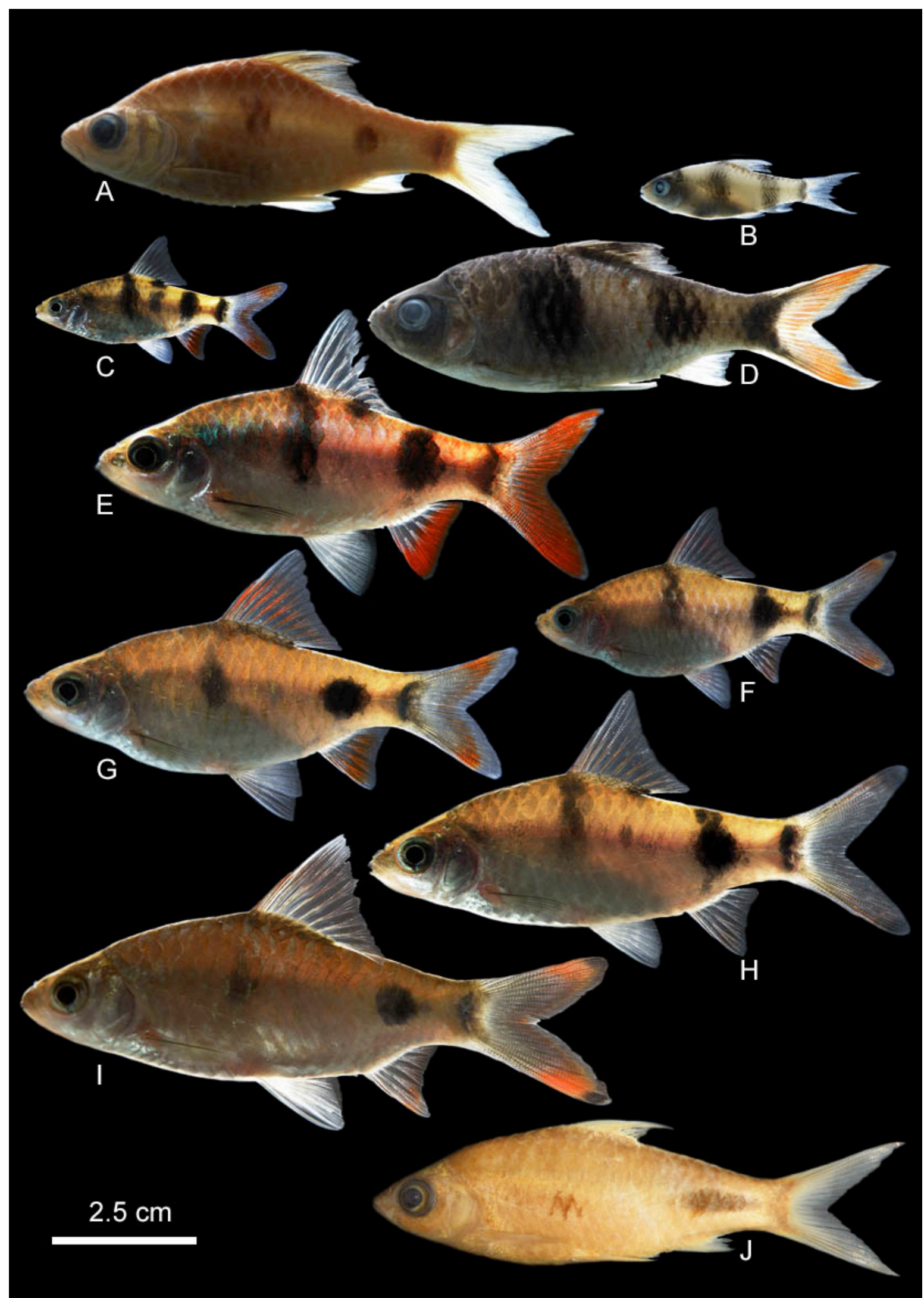

Image 2. A - Puntius rubrotinctus (ZSI/WGRC F3954, $62.7 \mathrm{~mm} \mathrm{SL);} \mathrm{B} \mathrm{-} \mathrm{P.} \mathrm{arulius} \mathrm{juvenile} \mathrm{(ATREE} \mathrm{unregistered,} 24.3 \mathrm{~mm}$ $\mathrm{SL}$ ); C - P. tambraparniei juvenile (Live/unregistered); D - P. arulius (ATREE unregistered, 79.8mm SL); E - P. tambraparniei (ZSI/SRS F8369, 57.0mm SL); F, G, H, I - Putative P. tambraparniei X P. filamentosus hybrids (Live/unregistered); J - $P$. exclamatio (ZSI/SRS F5520, 70.0mm SL). 
$57.3-57.6 \% \mathrm{SL}$ ), smaller interorbital width of 28.4 $35.6 \%$ HL (vs. 39.1-39.7 \% HL) and higher number of gill rakers 10(8)-11(4) gill rakers in the first gill arch (vs. 8(3)). It differs from P. tambraparniei and P. srilankensis in having a more terminal mouth as compared to the sub-terminal and inferior mouth of the latter, respectively, and absence of filamentous extensions to the branched dorsal fin rays of males (vs. presence in P. tambraparniei and P. srilankensis). It can further be differentiated from $P$. tambraparniei by its longer maxilla, which is $26.5-32.3 \% \mathrm{HL}$ (vs. $19.0-21.6 \% \mathrm{HL}$ ) and from $P$. srilankensis by a longer head length 28.3-32.8 \% SL (vs. 24.8-26.7\% SL), greater body depth of 34.9-41.8 \% SL (vs. 28.0-31.9 $\% \mathrm{SL}$ ), smaller interorbital width of $28.4-35.6 \% \mathrm{HL}$ (vs. 37.8-42.5 \% HL), and longer barbels $7.3-13.4 \%$ HL (vs. 0.0-1.8\% HL).

\section{Description}

Morphometric data of 12 specimens are given in Table 1. General body shape and appearance as in Image 1 and Image 2A. Body elongate, laterally compressed; dorsal contour ascending, indented at nape, profile of back convex anterior to dorsal-fin origin, tapering gradually thereafter; ventral profile equally convex anterior to pelvic-fin origin, curving gently up to analfin origin; caudal peduncle deep, its depth a little less than its length. Head length 28.3-32.8 \% SL; eye large, its diameter 29.3-35.8 \% HL, positioned nearer to snout than to opercular margin; interorbital wide, almost equal to eye diameter; snout length less than eye diameter; males with a few minute tubercles on snout, extending up to infra-orbital region. Mouth terminal; lips thick, maxilla extending almost to anterior border of eye. A pair of short maxillary barbels present, 7.3$13.4 \% \mathrm{HL}$. Dorsal fin inserted nearer to tip of snout than to caudal-fin base, with three simple and $81 / 2$ branched rays, its distal margin slightly concave. Anal fin with three simple and $5 \frac{1}{2}$ branched rays. Pelvic fin with one simple and eight branched rays, its origin slightly posterior to dorsal-fin origin. Pectoral fin with one simple and 13(7) or 14(5) branched rays. Pectoral and pelvic fins short, not reaching pelvic and analfin origins, respectively. Caudal fin with $1+9+8+1$ principal rays, deeply forked, with pointed lobes. 7(4)$8(8)$ predorsal scales. Lateral line complete, with 20 (1), 21(10) or 22(1) scales on body including one scale on caudal-fin base. Transverse scales from dorsal- fin origin to pelvic-fin origin $1 / 24+1+2$. An axillary pelvic scale present. Eighteen circumferential scales (counted as number of scales around greatest depth of body beginning from first scale anterior to dorsal-fin origin), 12 circumpeduncular scales. Well-defied gill rakers, 2(6), 3(6) + 7(2), 8(10) on the first gill arch.

\section{Coloration}

Formalin-fixed and alcohol-preserved specimens light brown above with a cream underside with three black, well-defined mid-body blotches, the first below the dorsal fin, the second above the anal fin, and the third on the caudal-fin base. Preserved specimens over time lose pigments and the blotch below the dorsal fin resembles the letters W or M. All fins hyaline.

\section{Distribution}

The type locality of P. rubrotinctus is Manantoddy River (= Mananthavadi River) which falls in the Kabini River drainage in the Wyanad District of Kerala. Also specimens from Bhavali River drainage and Moyar River drainage in Karnataka and Tamil Nadu were examined showing that $P$. rubrotinctus is widespread in the Cauvery and its tributaries across the States of Karnataka, Kerala and Tamil Nadu.

\section{DISCUSSION}

Even though Kortmulder (1972) highlighted the similarities between the juveniles and adults of $P$. filamentosus and $P$. arulius, it was the revision of the $P$. filamentosus group by Pethiyagoda \& Kottelat (2005) which brought $P$. filamentosus and $P$. arulius under the same group on the basis of their treating the juvenile colour pattern of these fishes as synapomorphic. The $P$. filamentosus group currently involves eight valid species, six of which are endemic to India: Puntius arulius (Jerdon), P. assimilis (Jerdon), P. exclamatio Pethiyagoda \& Kottelat, P.filamentosus (Valenciennes), P. rohani Devi et al. and P. tambraparniei (Silas), and two to Sri Lanka: P. singhala (Duncker) and P. srilankensis (Senanayake). Of these Puntius arulius, $P$. rubrotinctus, $P$. tambraparniei and $P$. srilankensis can be termed as the ' $P$. arulius group of fishes', characterized by three mid-body blotches in adults, in comparison to the other members of the $P$. filamentosus group, which have either a single blotch 
above the anal fin in the case of $P$. filamentosus, $P$. assimilis and P. singhala, or two blotches in the case of P. exclamatio. Due to their resemblance to each other, $P$. tambraparniei was considered a subspecies of $P$. arulius (Silas 1953; Jayaram 1991; Jayaram 1999; Menon 1999), as was P. srilankensis (Jayaram 1991; Jayaram 1999) until Pethiyagoda \& Kottelat (2005) restored them as valid species.

Puntius arulius was described by Jerdon (1849) as a fish with "a large diffused black blotch on side beneath the commencement of the dorsal fin, another over the anal, and another at base of caudal" and in the same work he describes $P$. rubrotinctus a species with " 3 small black spots on sides, one under dorsal, the $2^{\text {nd }}$ over the anal and the $3^{\text {rd }}$ near base of caudal" clearly distinguishing it from the large diffused blotches seen in P. arulius. Day (1878), in his work on the Fishes of India placed $P$. rubrotinctus as a synonym of $P$. arulius. He described a fish from Wayanad with three small spots as $P$. arulius (plate CXLII, fig 5 in Day 1878 ) with a pair of barbels, which he mentions were possibly overlooked in the original description by Jerdon (1849).

Though Jerdon (1849) just mentions $P$. arulius is called 'aruli' at Shrirangapattana he clearly mentions that he procured P. rubrotinctus from the Mananthavadi River, which flows into the Kabini, a tributary of the Cauvery that flows through the small town, Mananthavadi, in the Wyanad District of Kerala. Jerdon's (1849) Manantoddy River (= Mananthavadi River) flows into the Kabini, which is a tributary of the Cauvery that flows through the small town, Mananthavadi, in the Wyanad District of Kerala. Therefore the fish described by Day (1878) from Wayanad was clearly $P$. rubrotinctus and not $P$. arulius. Currently $P$. arulius is known from Coorg in the Cauvery River drainage (Pethiyagoda \& Kottelat 2005) and the Tungabadra River basin (Arunachalam et al. 2005), based on recent collections. Puntius runrotinctus is known from, Wayanad (Day 1878), Moyar River drainage in the Nilgiris, and from the Cauvery River drainage in Coorg. Furthermore, $P$. arulius has been recorded from Travancore, Thenmalai, Kulathupuzha and Kottayam (Day 1878; Jenkins 1909; Mukerji 1932; Silas 1953; Menon 1999; Gopi 2000; Arunachalam et al. 2005; Arunachalam \& Murugan 2007). As no specimens were examined from the above locations in the present study, we are unable to confirm whether the fish identified as $P$. arulius by earlier authors was indeed $P$. arulius. While $P$. arulius has a relatively wide distribution, $P$. tambraparniei is restricted to the lower reaches of the Tambraparni River, while $P$. srilankensis is endemic to a single location in Sri Lanka.

A search for $P$. arulius at Shrirangapattana by Pethiyagoda \& Kottelat (2005) resulted in no specimens being collected; these authors mentioned that even the local fishermen were unable to identify photographs of the fish. They concluded that the $P$. arulius had been extirpated in that locality, as the river had been impounded upstream. However Arunachalam et al. (2005) extended the range of $P$. arulius to the Tungabhadra River drainage, which is also an east flowing drainage flowing from the Western Ghats, similar to the Cauvery.

Recent survey of the Bhadra River resulted in fresh specimens of $P$. arulius being collected on comparing these with the specimens of $P$. arulius-like fish from Kabini River deposited in ZSI/SRS, it was clear that two distinct species are involved. The $P$. arulius collected from Bhadra matched the description given by Jerdon (1849) by having three large, diffused, saddle shaped blotches, the first one 4 scales high and three scales wide, the second 2 scales wide and 3 scales high, and the third covering the entire caudal-fin base. On the other hand the fish from Kabini had three small blotches consistent with Jerdon's (1849) original description of $P$. rubrotinctus. It is clear therefore that $P$. rubrotinctus is a valid species and not a synonym of $P$. arulius. Further examinations of specimens deposited in ZSI/SRS revealed the presence of $P$. rubrotinctus in Bhavali River drainage $\left(\sim 11^{\circ} 55^{\prime} \mathrm{N} \& 76^{\circ} 45^{\prime} \mathrm{E}\right)$ and the Moyar River drainage $\left(\sim 11^{\circ} 31^{\prime} \mathrm{N} \& 76^{\circ} 42^{\prime} \mathrm{E}\right)$ in Karnataka and Tamil Nadu respectively.

Puntius rubrotinctus can be distinguished still further from $P$. arulius and the other members of the $P$. arulius group also by possessing a more terminal mouth position, compared to subterminal in P. tambraparniei and inferior in P. srilankensis. Puntius tambraparniei can be distinguished from $P$. arulius, $P$. rubrotinctus and $P$. srilankensis by the presence of an additional spot at the posterior base of the dorsal fin, clearly visible also in juveniles (Image 2C).

Though Pethiyagoda \& Kottelat (2005) restricted the range of $P$. arulius to the Cauvery River basin, 
other authors have shown a wider range of $P$. arulius extending up to Tenmalai reservoir in southern Kerala (Day 1878; Jenkins 1909; Mukerji 1932; Silas 1953; Menon 1999; Gopi 2000; Arunachalam \& Murugan 2007) with Arunachalam et al. (2005) confirming the presence of a fish very closely ressembling $P$. arulius from Thenmalai, Kulathupuzha and Kottayam.

Incidentally Thenmalai is the type locality of $P$. exclamatio which gives rise to the question whether $P$. exclamatio is a hybrid between the $P$. arulius likefish and the widespread P. filamentosus as that (i.e., $P$. exclamatio) is the only fish in this group which has a mid-body ' $\mathrm{W}$ ' shaped blotch like $P$. rubrotinctus, which belongs to the $P$. arulius group and an elongated caudal peduncle blotch which resembles the other fishes of the $P$. filamentosus group. Moreover $P$. exclamatio was described as a fish with sub-terminal mouth (Pethiyagoda \& Kottelat 2005) but the specimen collected from Kallada River which we observed had terminal mouth which is the character of P. rubrotinctus. Pethiyagoda \& Kottelat (2005) stated that the males of $P$. exclamatio lacked the filamentous prolongations of the dorsal-fin branched rays. In our earlier work (Devi et al. 2010) we attributed this to seasonal shedding of the filaments as the specimens we observed from Kallada possessed dorsal fin filaments; but the lack of the dorsal fin filaments in some populations of $P$. exclamatio could also be attributed to hybridization as P. rubrotinctus too, lacks dorsal filaments. Moreover a specimen of $P$. exclamatio we observed from Varkala, Kallada River drainage in Kerala had black caudal-fin tips, which are characteristic of $P$. filamentosus (Image 2J).

To add impetus to the question of possible hybridization within the $P$. filamentosus group of fishes, we found intermediate forms between $P$. filamentosus and P. tambraparniei (Image 2 F, G, H, I) at Cheramadevi in Tambraparni River drainage. These intermediate fishes were found where $P$. filamentosus and $P$. tambraparniei co-existed in the Tambraparni River at Cheremadevi. These intermediate fishes either resembled $P$. filamentosus with an extra midbody blotch, which is a character of $P$. tambraparniei or they looked like P. tambraparniei with a black bar on the tips of the caudal fin, which is a character of P. filamentosus absent in the typical P. tambraparniei. The possibility of these two species hybridizing is high as they are closely related and the exchange of genes among $P$. arulius and $P$. filamentosus has already been speculated (Arunachalam \& Murugan 2007) and could be the reason for the high genetic variation among $P$. filamentosus in the Tambraparni drainage (Johnson et al. 2007).

Hybridization in cyprinidae is more common than in any other group of freshwater fish (Scribner et al. 2000). Hybridization in the genus Puntius was investigated by Kortmulder (1972) and he produced viable hybrids by crossing $P$. conchonius $\times$ P. stoliczkanus, $P$. cumingi $\times P$. nigrofasciatus and $P$. stoliczkanus $\times P$. nigrofasciatus. He even observed fertile eggs being produced in a cross between a $P$. conchonius female and $P$. filamentosus male and speculated that the reason for the larvae not surviving could also be due to certain specific conditions of the experiment.

Recent studies have shown that hybridization does lead to adaptation through the creation of new genes and morphologies (Seehausen 2004; Bell \& Travis 2005; Pfennig et al. 2007; Schwenk et al. 2008; Hayden et al. 2010). Some of these hybrids are fertile (Wood \& Jordan 1987; Wyatt et al. 2006; Hayden et al. 2010) and possess unique phenotypic characters which are intermediate between the parental species, which helps them exploit niches unavailable to the parental species, thereby out-competing them, particularly in novel habitats (Seehausen 2004; Nolte et al. 2005). Thus the presence of intermediate forms in the P. filamentosus group could also be attributed to hybridization as it plays a role in adaptive radiation and the evolution of new lineages. We hope to investigate this question further in the Puntius filamentosus group by future genetic studies.

\section{Comparative material}

Puntius arulius: 24.xi.2010, 3 ex., 24.3-79.8 $\mathrm{mm}$ SL, Iron bridge near KIOCL plant, $13^{0} 12^{\prime} 21^{\prime} \mathrm{N}$ \& $75^{\circ} 14^{\prime} 47^{\prime \prime} \mathrm{E}$, Bhadra River drainage, ATREE unregistered, coll. Vidyadhar Atkore.

Puntius tambraparniei: 11.i.2010, 1 ex., 57.0mm SL, Tirunelveli Town, Tambraparani River drainage (8044'12'N \& 77043'7'E), ZSI/SRS F.8369; coll. J.D. Marcus Knight; 9.iv.1995, 10 ex., 40.3-53.2 mm SL, Kodaimel Azhakian Anicut, Tambraparani River drainage ( $\left.8^{0} 42^{\prime} \mathrm{N} \& 7^{\circ} 22^{\prime} \mathrm{E}\right)$, ZSI/SRS F.4452, coll. M.B. Raghunathan.

Putative Puntius tambraparniei X Puntius 
filamentosus hybrids: 26.viii.2010, 7 ex., 32.0-68.0

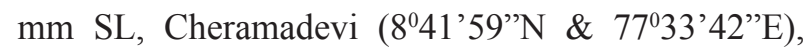
Tambraparani River drainage, Live/unregistered; coll. J.D. Marcus Knight.

Puntius exclamatio: 03.iv.1998, 1 ex., 70.0mm SL, Varkala ( $\left.8^{\circ} 53^{\prime} \mathrm{N} \& 76^{\circ} 42^{\prime} \mathrm{E}\right)$, Kallada River draiange, ZSI/SRS F5520, coll. P.T. Cherian.

\section{REFERENCES}

Arunachalam, M., J.A. Johnson, A. Manimekalan, A. Sankaranarayanan, R. Soranam, P. Sivakumar \& M. Muralidharan (2005). Extension range of Puntius arulius arulius (Jerdon) in various streams in Thungabadra River basin. Journal of the Bombay Natural History Society 102(3): 343-344.

Arunachalam, M. \& M. Murugan (2007). Cytogenetic and cytotaxonomic considerations of two endangered ornamental fishes Puntius arulius and P. tambraparniei (Cypriniformes: Cyprinidae) from Western Ghats, India. Zoos' Print Journal 22(7): 2739-2741.

Bell, M.A. \& M.P. Travis (2005). Hybridization, transgressive segregation, genetic covariation, and adaptive radiation. Trends in Ecology and Evolution 20(7): 358-361.

Day, F. (1878). The Fishes of India; Being a Natural History of the Fishes Known to Inhabit the Seas and Freshwaters of India, Burma and Ceylon. Bernard Quaritch, Piccadilly, London, $\mathrm{xx}+778 \mathrm{pp}, 196 \mathrm{pls}$.

Devi, K., T.J. Indra \& J.D.M. Knight (2010). Puntius rohani (Teleostei: Cyprinidae), a new species of barb in the Puntius filamentosus group from the southern Western Ghats of India. Journal of Threatened Taxa 2(9): 1121-1129.

Gopi, K.C. (2000). Freshwater fishes of Kerala State, pp. 57-76. In: Ponniah, A.G. \& A. Gopalakrishnan (eds.). Endemic Fish Diversity of Western Ghats. NBFGR/NATP Publication, 1: 347pp.

Hayden B., D. Pulcini, M. Kelly-Quinn, M. O’Grady, J. Caffrey, A. McGrath \& S. Mariani (2010). Hybridisation between two cyprinid fishes in a novel habitat: genetics, morphology and life-history traits. BMC Evolutionary Biology 10: 169.

Jayaram, K.C. (1991). Revision of the genus Puntius (Hamilton) from the Indian Region (Pisces: Cypriniformes, Cyprinidae, Cyprininae). Records of the Zoological Survey of India, Occasional Paper 135: 1-178.

Jayaram, K.C. (1999). The Freshwater Fishes of the Indian Region. Narendra Publishing House, New Delhi, 551pp.

Jenkins, J.T. (1909). Fish from Travancore and Cochin. Records of the Indian Museum 3: 287-293.
Jerdon, T.C. (1849). On the freshwater fishes of southern India. Madras Journal of Literature and Science 15: 302-346.

Johnson, J.A., R.P. Rajesh, L.A. Mary \& M. Arunachalam (2007). Comparative analysis of inter population genetic diversity in Puntius filamentosus using restriction fragment length polymorphism (RFLP) analysis. African Journal of Biotechnology 6(23): 2682-2686.

Kortmulder, K. (1972). A comparative study in colour patterns and behaviour in seven Asiatic Barbus species (Cyprinidae, Ostariophysi, Osteichthyes). Behaviour, Supplement. 19, $331 \mathrm{pp}$.

Menon, A.G.K. (1999). Check list - fresh water fishes of India. Records of the Zoological Survey of India, Miscellaneous Publication, Occasional Paper No. 175, 366pp.

Mukerji, D.D. (1932). On a small collection of fish from the Bhavani River (S. India). Journal of the Bombay Natural History Society 35: 162-171.

Nolte, A.W., J. Freyhof, K.C. Stemshorn \& D. Tautz (2005). An invasive lineage of sculpins, Cottus sp (Pisces, Teleostei) in the Rhine with new habitat adaptations has originated from hybridization between old phylogeographic groups. Proceedings of the Royal Society B: Biological Sciences 272(1579): 2379-2387.

Pethiyagoda, R. \& M. Kottelat (2005). A review of the barbs of the Puntius filamentosus group (Teleostei: Cyprinidae) of Southern India and Sri Lanka. Raffles Bulletin of Zoology Supplement 12: 127-144.

Pfennig, K.S. (2007). Facultative mate choice drives adaptive hybridization. Science 318(5852): 965-967.

Scribner, K.T., K.S. Page \& M.L. Bartron (2000). Hybridization in freshwater fishes: a review of case studies and cytonuclear methods of biological inference. Reviews in Fish Biology and Fisheries 10(3): 293-323.

Schwenk K., N. Brede \& B. Streit (2008). Introduction. Extent, processes and evolutionary impact of interspecific hybridization in animals. Philosophical Transactions of the Royal Society B: Biological Sciences 363(1505): 28052811.

Seehausen, O. (2004). Hybridization and adaptive radiation. Trends in Ecology and Evolution 19(4): 198-207.

Silas, E.G. (1953). New fishes from the Western Ghats, with notes on Puntius arulius (Jerdon). Records of the Indian Museum 51(1953[1954]): 27-37.

Wood A.B. \& D.R. Jordan (1987). Fertility of roach X bream hybrids, Rutilus rutilus $(\mathrm{L}) \times$ Abramis brama $(\mathrm{L})$, and their identification. Journal of Fish Biology 30(3): 249-261.

Wyatt P.M.W., C.S. Pitts \& R.K. Butlin (2006). A molecular approach to detect hybridization between bream Abramis brama, roach Rutlius rutilus and rudd Scardinius erythrophthalmus. Journal of Fish Biology 69: 52-71. 